\title{
AVALIAÇÃO NA EDUCAÇÃO FÍSICA ESCOLAR: RECONHECENDO A ESPECIFICIDADE DE UM COMPONENTE CURRICULAR
}

\author{
EVALUATION OF SCHOOL PHYSICAL EDUCATION: RECOGNIZING IT AS A \\ SPECIFIC CURRICULUM COMPONENT
}

\author{
EVALUACIÓN EN LA EDUCACIÓN FÍSICA ESCOLAR: RECONOCIENDO LA \\ ESPECIFICIDAD DE UN COMPONENTE CURRICULAR
}

\author{
Wagner dos Santos*, Bruna Jéssica Mathias*, Juliana Martins Cassani Matos*, \\ Aline Oliveira Vieira**
}

\section{Palavras-chave}

Ensino fundamental e médio.

Avaliação educacional. Narração.
Resumo: 0 estudo busca analisar as possibilidades e as necessidades de se produzir práticas avaliativas na Educação Física que levem em consideração os saberes valorizados pela educação escolarizada e pelas especificidades dessa disciplina. Utiliza a pesquisa narrativa autobiográfica como referencial teórico-metodológico e define, como colaboradores, alunos do primeiro ao quarto ano do ensino fundamental de uma escola municipal da Prefeitura de Serra/Espírito Santo. Possui como fontes desenhos, atividades pedagógicas escritas e diários de Educação Física. Esses instrumentos avaliativos possibilitaram aos discentes narrar as suas experiências corporais mediante a transformação dos saberes de domínio e relacionais em saberes-objeto
Keywords

Education, primary and secondary.

Educational measurement. Narration.
Abstract: The study aims to analyze the possibilities and the needs to produce evaluation practices in physical education that take into account the knowledge valued by school education and the specificities of that discipline. It uses autobiographical narrative research as a theoretical and methodological framework. Subjects are students of the 1st-4th grade elementary school in a municipal school in Serra, Espírito Santo, Brazil. Its sources include drawings, written pedagogical activities and physical education diaries. These evaluation instruments enabled students to narrate their body experiences by transforming mastery knowledge and relational knowledge into object-knowledge.
Palabras clave

Educación primaria y secundaria.

Evaluación educacional. Narración.
Resumen: El estudio busca analizar las posibilidades y las necesidades de producir prácticas evaluativas en la Educación Física que lleven en consideración los saberes valorados por la educación escolarizada y por las especificidades de esa asignatura. Utiliza la investigación narrativa autobiográfica como referencia teórico-metodológica y define, como colaboradores, alumnos del primer al cuarto año de la enseñanza fundamental de una escuela municipal del Ayuntamiento de Serra/Espírito Santo. Posee como fuentes: dibujos, actividades pedagógicas escritas y diarios de Educación Física. Esos instrumentos evaluativos posibilitaron que los discentes narrasen sus experiencias corporales, mediante la transformación de los saberes de dominio y relacionales en saberes-objeto.
*Universidade Federal do Espírito Santo, Vitória, ES, Brasil.

E-mail: wagnercefd@gmail.com

** Rede Municipal de Ensino, Serra, ES, Brasil.

E-mail: ninna.manguinhos@gmail.com

Recebido em: 09-05-2014 Aprovado em: 24-09-2014 (c) (1) (8) Licence 


\section{INTRODUÇÃO}

A produção do conhecimento no campo da avaliação na Educação, sob diversos enfoques, tem sido objeto de intensos debates no Brasil desde a década de 1930. Nos últimos anos, a reflexão sobre essa temática intensificou-se produzindo movimentos de ordens e potencialidades diferentes. Entretanto, as análises das práticas avaliativas na Educação Física ganham fôlego somente em meados da década de 1970, com o intuito de criar avaliações fidedignas e objetivas, influenciadas pelos trabalhos construídos na Educação, sobretudo os de Bloom, Pophan, Scriven, Stake, Stufflebeam e Tyler.

Paulatinamente, a construção do conhecimento na área e o intenso diálogo com referenciais sobretudo da Educação indicaram outras possibilidades teóricas pautadas na ética, nas diferenças e nos processos de aprendizagem, especialmente a partir das perspectivas de avaliação diagnóstica (CECHELLA, 1991), formativa (LUIS, 2010) e como prática indiciária (SANTOS, 2005, 2008). Essas concepções têm nos ajudado a compreender que não há uma prática avaliativa descontextualizada das perspectivas pedagógicas que lhes oferecem fundamento, pois não é o instrumento que determina a sua concepção, mas a intencionalidade do avaliador. Contudo, como a Educação Física tem enfrentado a questão da avaliação no cotidiano escolar?

Estudos como os de Hébrard (1990) têm demonstrado como as práticas culturais são sistematizadas na escola por meio de diferentes sistemas simbólicos, materializados em dispositivos de instrução que privilegiam a leitura e a escrita como aprendizagens anteriores a todas as disciplinas. Neste caso, é justamente o aprendizado focalizado nos saberes da leitura e da escrita que, traduzidos em testes e trabalhos, se transforma em processos avaliativos. Santos e Maximiano $(2013)$ e Santos $(2005,2008)$ têm discutido sobre os desafios para a Educação Física se adequar à lógica de avaliação presente no universo da escola e, ao mesmo tempo, anunciado, no diálogo com professores, outras perspectivas fundamentadas no modo como os sujeitos se apropriam e produzem sentidos às suas experiências com as práticas.

Diante desse contexto, objetivamos, neste artigo, discutir sobre as possibilidades e as necessidades de se produzir práticas avaliativas que levem em consideração os saberes valorizados pela educação escolarizada e as especificidades da Educação Física como componente curricular. Pretendemos, com esse movimento, indicar caminhos, alternativas e possibilidades para se pensar em um processo avaliativo centrado nos sentidos produzidos pelos sujeitos na relação que estabelecem com o saber (CHARLOT, 2000).

Em um primeiro momento, delineamos a perspectiva teórico-metodológica norteadora da pesquisa. Posteriormente, analisamos as fontes em diálogo com a produção acadêmica, para, ao final, retomarmos as principais questões abordadas.

\section{TEORIA E METODOLOGIA}

A abordagem teórico-metodológica da pesquisa é a narrativa autobiográfica. Assim como a "[...] arte de evocar, narrar é atribuir sentidos às experiências" (SOUZA, 2006). Sua 
ação permite, pela exteriorização do conhecimento sobre si e das diversas dimensões dos saberes e fazeres pedagógicos, a construção de um processo de reflexão e interpretação das histórias de vida e dos percursos de apropriação dos saberes. Narrar-se pode contribuir para descobrir-se, conscientizar-se e (re)significar-se. Ao mergulharmos nas narrativas dos discentes das séries iniciais do ensino fundamental, buscamos o resgate das experiências rememoradas e compartilhadas nos instrumentos avaliativos produzidos nas aulas de Educação Física. ${ }^{1}$

A história que a pesquisa se propõe a visibilizar traz na colaboração dos alunos suas memórias, ruínas (BENJAMIN, 1994) revisitadas no presente que são narradas em um movimento de reminiscência entendida como "[...] uma cadeia de acontecimentos encarnada pelo narrador; ela tece uma rede de histórias comum entre si" (BENJAMIN, 1994, p. 205). O narrador, a partir de uma atividade mimética (BENJAMIN, 1994), seleciona experiências para rememorar e registrar, produzindo uma releitura dos acontecimentos que o marcaram.

Definimos como colaboradores da pesquisa os alunos do $1^{\circ}$ ao $4^{\circ}$ ano do ensino fundamental de uma escola municipal da Prefeitura de Serra/ES. A escolha da escola foi realizada mediante pesquisa anterior (SANTOS; MAXIMIANO, 2013), na qual identificamos o uso do diário de Educação Física como prática avaliativa da professora. As turmas foram sugeridas pela própria docente, já que, com base no domínio dos alunos sobre a linguagem escrita, diferentes instrumentos de avaliação foram produzidos.

Consideramos como fonte todo o material imagético (ALVES, 2007) produzido pelos alunos, expresso nos desenhos, nas atividades pedagógicas escritas e nos diários de Educação Física. A professora fez uso dos desenhos com os alunos do $1^{\circ}=$ ano por ainda não dominarem a escrita, em um total de 16 registros. Os alunos do $2^{\circ}$ ano desenvolveram 20 atividades pedagógicas escritas e 21 desenhos, enquanto os discentes do 3 ano produziram 36 diários, dos quais 20 são acompanhados de desenhos. Já no 4ํano, os diários foram escritos por 23 alunos. Esses materiais foram analisados não como dados, mas como produtos (CERTEAU, 1994), consequência da ação cultural vivenciada pelos discentes nos lugares e espaços da instituição escolarizada.

\section{DA CONCEPÇÃO DE AVALIAÇÃO À POSSIBILIDADE DE USO DOS REGISTROS ICO- NOGRÁFICOS COMO INSTRUMENTOS}

A professora de Educação Física tem assumido como eixo central de sua prática pedagógica o desenvolvimento de projetos articulados com os professores de diferentes componentes curriculares, como o "Identidade Cultural". Com o objetivo de conhecer as identidades das famílias que faziam parte daquela comunidade escolar, ela solicitou aos alunos do 20 ano que pesquisassem sobre as brincadeiras, as vestimentas e a culinária relacionadas com a infância de seus ascendentes, conforme Figura 1:

1 A pesquisa foi aprovada pelo Comitê de Ética da Ufes sob o número 15419913.4.0000.5542. Os alunos assinaram termo de Assentimento Livre e Esclarecido e os responsáveis o termo de Consentimento, autorizando a pesquisa e a divulgação das imagens. 
Figura 1 - Desenho "Minha identidade cultural"

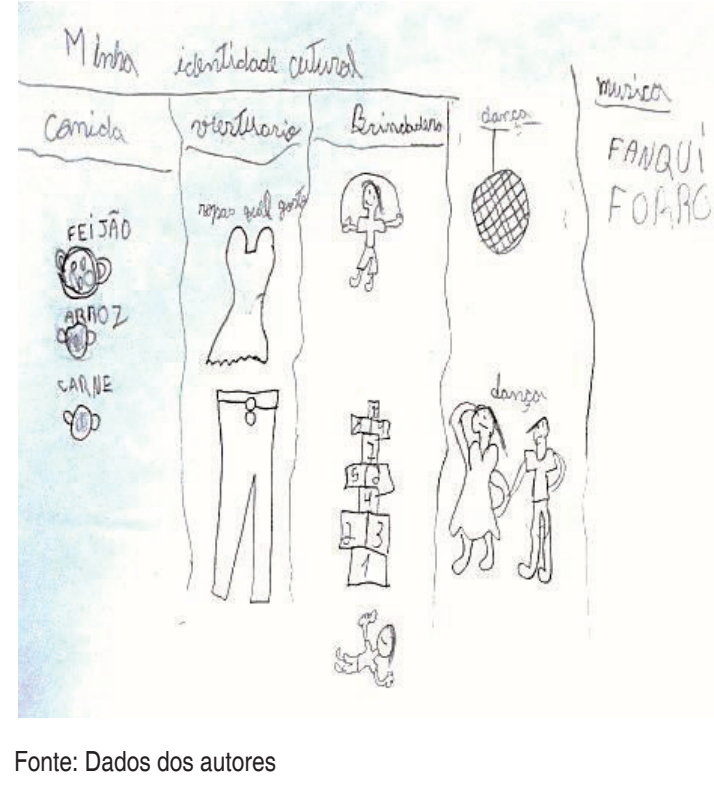

Os alunos indiciaram em seus desenhos as experiências de movimento vividas por seus pais, dentre elas, o pular-corda, o brincar de amarelinha e de comidinha, assim como fizeram uso da escrita para expressar as suas preferências. De acordo com Ramos, Panozzo e Zanolla (2011) e Lopes (2008), as linguagens verbais e visuais se configuram em representações de uma realidade social e coletiva, pontos referenciais das manifestações culturais que possuem discursividades específicas. Por meio dos desenhos, os alunos não retrataram apenas os elementos presentes em seu cotidiano, mas também visibilizaram as leituras que operam sobre a cultura na qual estão inseridos, se autoprojetando nos registros. Ao construir para si uma cultura, a aluna escreve e desenha o tipo de roupa que mais gosta e sinaliza possibilidades para o ensino da dança, ao escrever o nome de estilos musicais com os quais se identifica, como o funk e o forró.

Usar o desenho com o objetivo de compreender como os alunos constroem e reconstroem as suas identidades a partir das características da comunidade em que se inserem revela a intencionalidade da professora em identificar se as crianças conheciam, ou não, as práticas locais, em um movimento de valorização da sua cultura. A ausência do congo nos desenhos, uma manifestação típica da região onde a escola está inserida, acenou para a necessidade de se discutir com os alunos o conceito de identidade, de cultura e de identidade cultural.

As práticas produzidas pela docente sinalizam o uso dos registros imagéticos como um instrumento avaliativo do tipo diagnóstico. ${ }^{2}$ Realizado no início do processo, o diagnóstico teve como objetivo produzir elementos para que a professora pudesse orientar e definir sua atuação pedagógica. $O$ reconhecimento dos saberes dos alunos se configurou como dimensão central do trabalho, partindo-se do que o aluno sabe, não sabe, ou ainda não sabe, para se definir seus processos de aprendizado.

A ação de avaliar demanda, portanto, uma atitude política de analisar a realidade, de interrogar e interrogar-se. Como prática de pesquisa, ela permite, por meio das pistas e dos in-

20 campo conceitual da avaliação apresenta três tipos avaliativos, definidos pelo momento e objetivo com que é realizado. No início do processo, a avaliação do tipo diagnóstica possui como objetivo predizer, orientar e projetar; durante o processo, a avaliação do tipo formativa busca adequar, ajustar; ao final de um momento predeterminado, a avaliação somativa visa a classificar e selecionar. No cenário da produção acadêmica, os tipos diagnóstica e formativa se transformaram em perspectiva, como podem ser vistos, respectivamente, em Luckesi (2000) e Hadji (1994). 
dícios produzidos pelos praticantes escolares ${ }^{3}$ evidenciar os processos de ensino-aprendizado construídos, em construção e ainda não construídos, oferecendo elementos para se projetar outros caminhos e percursos (SANTOS, 2005, 2008).

A professora também trabalhou com desenhos ao longo do trimestre, a fim de captar 0 que os alunos do $1^{\circ}$ ano aprenderam nas aulas de Educação Física. Alguns dos 16 desenhos mapeados encontram-se associados à escrita, como observado nas Figuras 2 e 3 :

Figura 2 - Desenho da Luana

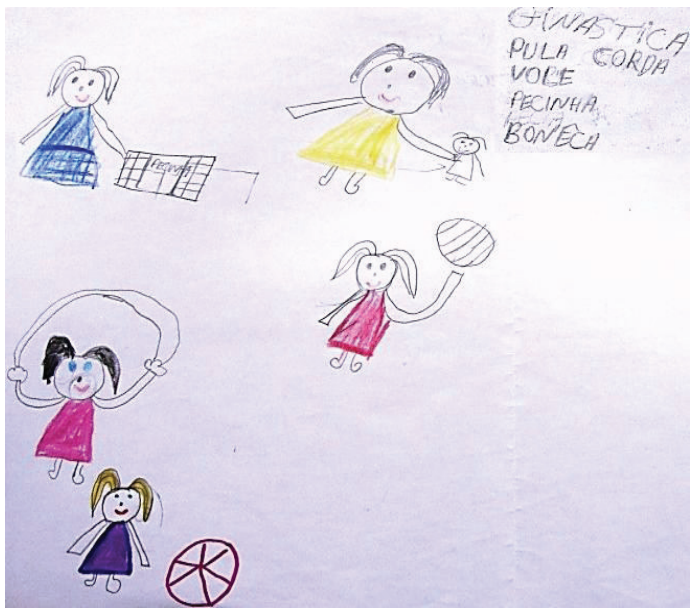

Figura 3 - Desenho da Ana Luiza

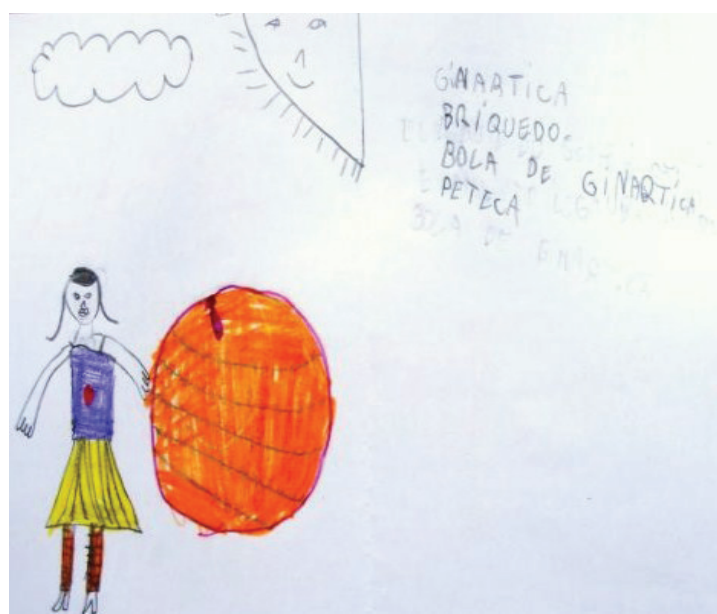

Fonte: Dados dos autores

As imagens e a escrita projetam o que foi vivenciado nas aulas, como pular corda, jogar vôlei, brincar de peteca e ginástica, no entanto o significado do aprendizado, ao se relacionar com o saber que é incorporado, diferencia-se em cada pessoa. Em ambas as figuras, as referências estéticas das crianças são ressaltadas no uso de diferentes cores e formas, elementos que as atraem e as estimulam em suas primeiras aproximações com a leitura (RAMOS; PANOZZO; ZANOLLA, 2011). Se, na leitura do texto, os desenhos não são secundários, pois ampliam a compreensão da linguagem textual, os recursos utilizados também nos sugerem as intencionalidades das crianças em narrar, por meio das imagens, as suas próprias experiências de aprendizagem tidas como significativas.

Na Figura 2, uma criança segura uma boneca no colo, remetendo-nos à confecção de bonecas de pano realizada nas aulas de Educação Física, o que nos indica, pela roupa e pelo cabelo, que seria ela própria a segurando. Ao se desenhar brincando de boneca, a criança pode entrar em um universo imaginário e se apropriar de uma cultura do adulto, mas, ao mesmo tempo, fortalece sua condição como categoria geracional que tem, no brincar, uma das principais linguagens. Para Borba (2007), as crianças se constituem, ao brincar, como sujeitos de experiência social, organizando com autonomia suas ações e interações, elaborando planos e formas de ações conjuntas, criando regras de convivência social e de participação nas brincadeiras. Elas não apenas reproduzem uma cultura adulta, mas, no consumo que estabelecem com essa cultura, inventam outras formas de aprendizado.

A Figura 3 evidencia a Educação Física como uma disciplina que oportuniza à aluna aprender os conteúdos em outros espaços da escola, como os ambientes externos que, em grande parte, se encontram associados à quadra, ao pátio ou, revelando a especificidade da 
escola estudada neste trabalho, ao terraço. Em cinco dos dezesseis desenhos produzidos, encontramos paisagens como o Sol, as nuvens, as árvores e as flores. De acordo com Diógenes (2004), as imagens de espaços representados expressam, com frequência, as experiências individuais e coletivas produzidas pela relação estabelecida com um determinado ambiente e as cumplicidades que narram um sentido singular de um grupo. $O$ diálogo com a autora nos leva à compreensão de que, ao especificar o espaço em que aprendem os saberes da Educação Física, as crianças rememoram as identidades produzidas por/para aquele grupo de alunos pela relação que elas estabelecem com o terraço.

Em todas as imagens, encontramos a presença dos discentes vivenciando as atividades. Fazer aula de Educação Física, em suas concepções, é experimentar e dominar uma prática corporal com ou sem a presença de diferentes objetos, como a corda, a bola e os brinquedos. Neste caso, não basta ter o objeto, é necessário estabelecer a relação de domínio com ele, produzindo a sua própria experiência corporal. Depreendemos desse debate que a criança não aprende apenas quando lê, escreve e fala. Aprende também quando se expressa corporalmente, uma vez que o movimentar-se não pode ser considerado apenas natural, espontâneo, biológico; relaciona-se, principalmente com questões culturais, afetivas e sociais (SCHNEIDER; BUENO, 2005).

Os instrumentos utilizados pela professora demonstram a perspectiva que tem fundamentado as suas práticas pedagógicas e avaliativas. As análises dos registros, que evidenciam a avaliação como um espaço de registro e interpretação de sentidos, são baseadas no exercício constante de leituras de sinais e de indícios a partir dos quais se manifestam juízos de valor e tomadas de decisão (SANTOS, 2008). No entanto, como compreender as narrativas dos alunos sobre os sentidos atribuídos ao que foi ensinado, sobre as suas experiências corporais, levando em consideração o saber que confere especificidade à Educação Física? Como tomar como referência os sinais e indícios registrados nos instrumentos avaliativos de forma a potencializar a aprendizagem dos alunos?

Para compreendermos o saber que significa essa disciplina no cotidiano escolar e a necessidade de mudança de compreensão sobre o que seria avaliar na Educação Física Escolar, apropriamo-nos das teorias de Charlot (2000) acerca do saber e das figuras do aprender. $\mathrm{O}$ autor afirma que $\mathrm{o}$ aprender pode se constituir em uma apropriação de um saber que não se possui e cuja forma de existência se inscreve em livros, monumentos ou obras de arte, chamado de saber-objeto; pode se relacionar ainda com uma forma de domínio de uma atividade ou com a utilização de um objeto de maneira pertinente, em que se passa do não domínio ao domínio de uma atividade. É um saber que se inscreve em um lugar de apropriação do mundo, de um conjunto de significações passadas, o corpo, e é denominado saber de domínio. $O$ aprender também se constitui em uma relação epistêmica de domínio, porém não de uma atividade, mas de uma relação. $O$ aprender é tornar-se capaz de regular a relação consigo mesmo, com os outros e encontrar a distância conveniente entre si e os outros, intitulado saber relacional.

A escola, como o lugar da palavra e de outras formas de simbolização do mundo, dos saberes sistematizados, cujo modo de existência é a linguagem verbal, tende a valorizar as disciplinas que privilegiam saberes relacionados com a objetivação-denominação (SANTOS; MAXIMIANO, 2013). Já a Educação Física assume um estatuto epistêmico que tem outra relação com o saber, quando comparada com os demais componentes curriculares. Ao privilegiar a 
dimensão do saber de domínio, que se centraliza no fazer com (SCHNEIDER; BUENO, 2005), ela redimensiona a forma escolar.

Mas se, por um lado, essa disciplina (re)significa o universo da escola, por outro, tem que se adequar a ele, ou seja, ao mesmo tempo em que a Educação Física opera com as lógicas e procedimentos que oferecem fundamento à forma escolar, como é o caso da nota, também a subverte na medida em que estabelece a relação do "[...] corpo-sujeito com o mundo, um mundo compartilhado com outros, uma forma incorporada de ser dono de si mesmo e do seu ambiente" (CHARLOT, 2009, p. 244). Nesse ponto, compartilhamos das leituras de Charlot (2009, p. 243), quando salienta:

[...] a Educação Física não é uma disciplina escolar 'como as demais' [...]. Não é igual às demais porque ela lida com uma forma do aprender que não a apropriação de saberes-enunciados. Em vez de tentar anular ou esconder essa diferença, dever-se-ia destacá-la e esclarecê-la. $O$ fato de que é uma disciplina diferente não significa que tem menos legitimidade do que as demais disciplinas.

Dar visibilidade às subjetividades encarnadas na experiência de cada praticante nos faz pensar em uma perspectiva de avaliação fundamentada no estatuto epistemológico da Educação Física e, ao mesmo tempo, apresenta-nos possibilidades de registro que evidenciam o modo como os discentes se relacionam com o saber. Como veremos na Figura 4, a atividade "montando frases" se constitui em uma alternativa para compreender como os alunos expressam, por meio da escrita, as suas aprendizagens:

Figura 4 - Atividade "Montando frases"

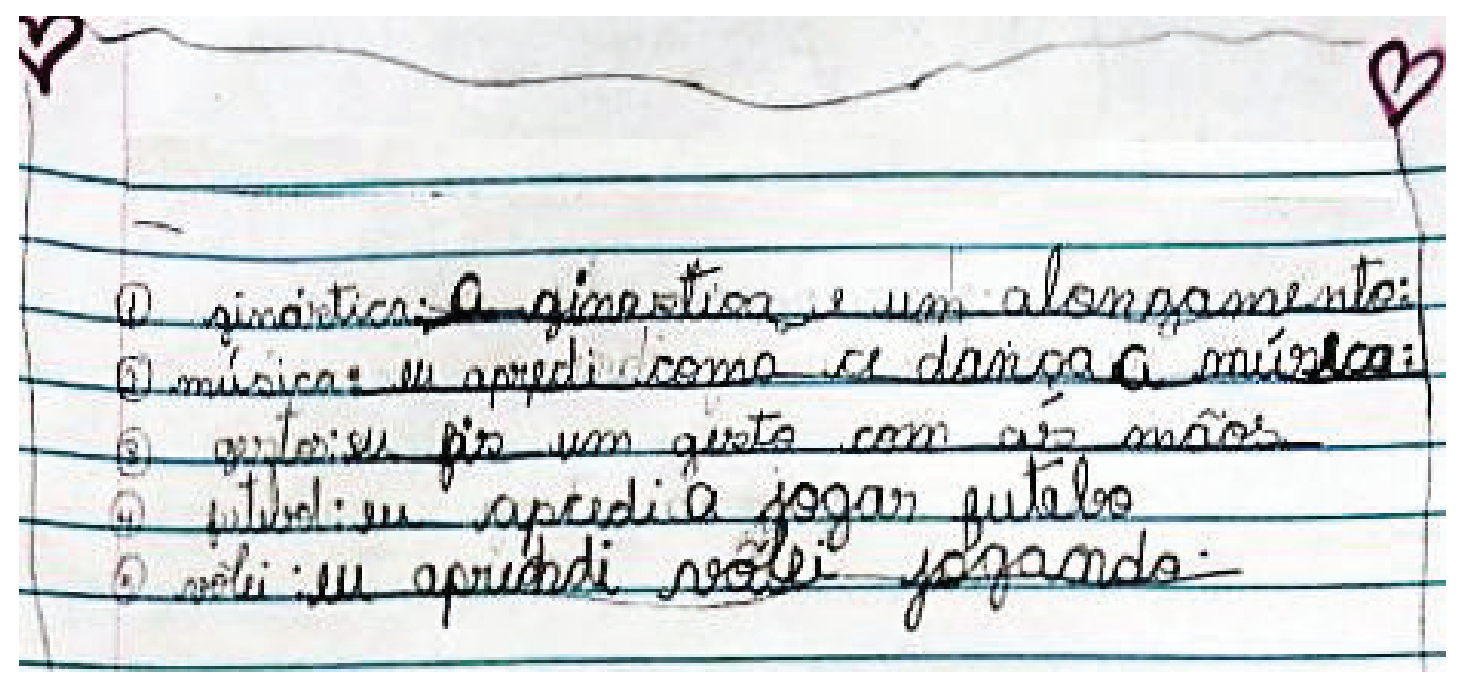

Legenda:

ginástica: A ginastica e um alongamento música: eu apredi como ce dança A música gestos: eu fis um gesto com as mãos futebol: eu apredi a jogar futebo vôlei: eu aprendi võlei jogando Fonte: Dados dos autores

Produzida por alunos do $2^{\circ}$ ano, a atividade teve como objetivo entender o que aprenderam ao final de 2011. Assim, a professora indicou algumas palavras-chave para que, individualmente, eles construíssem frases relacionadas com as suas aprendizagens. Em todas as temáticas sugeridas, a criança escreve sobre como incorporou os saberes nas aulas de Educação Física: por meio da experimentação corporal. Entretanto, especificamente com a ginástica, 
ela demonstra que se apropriou do conteúdo não apenas pelo domínio corporal, mas, ao the designar um conhecimento, o alongamento, demarca que o seu aprendizado também passa pela transformação da atividade em domínio cognitivo, o saber-objeto, revelando a compreensão do saber e seu uso em um determinado contexto.

Por ter sido realizada ao final do ano, essa atividade poderia se configurar, sob o ponto de vista da professora, como uma avaliação somativa na qual se privilegiaria o produto final, o resultado da aprendizagem do aluno. Para Luckesi (2011), compreender a avaliação como uma quantificação do aprendizado seria classificar, excluir temporária ou definitivamente os alunos que não obtêm êxito em seu desempenho final. Essa forma de avaliar está relacionada com processos de classificação, em que provas, conceitos, aprovação e reprovação (ESTEBAN, 2003) se constituem em eixos centrais da prática avaliativa que, no caso da Educação Física, responderia e atenderia à lógica escolar.

No entanto, a preocupação da docente não era atribuir uma nota, mas compreender 0 modo como os alunos davam sentidos às suas experiências, ou seja, a relação que eles estabeleciam com o saber e os sentidos produzidos nessa relação. Foi com esse intuito que ela implementou como instrumento avaliativo o diário de Educação Física. Cada aluno tem o seu diário que se configura como um dispositivo de registros dos saberes aprendidos, como pode ser visto na Figura 5.

Figura 5 - Diário de Lorena sobre o que gostaria de aprender

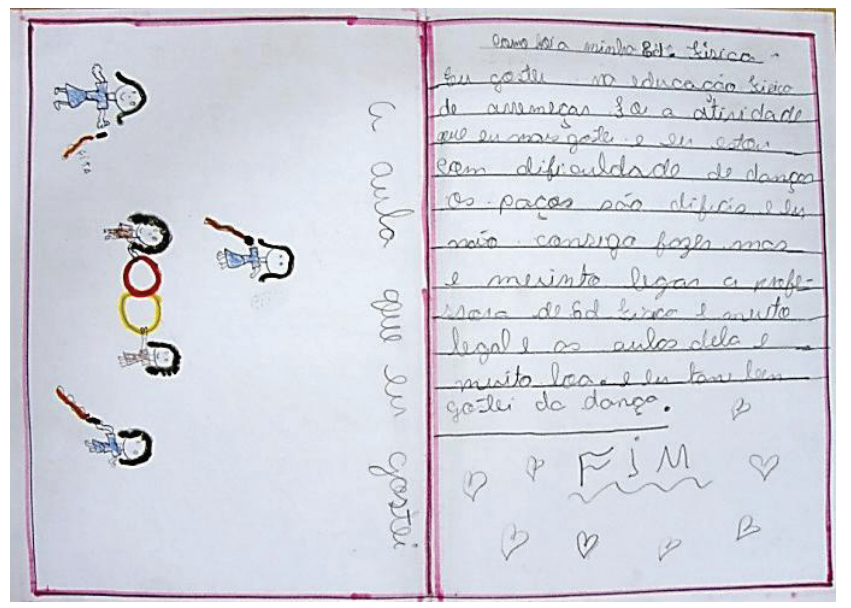

Legenda:

"Como foi a minha Ed. Fisica.

Eu gostei na educação fisica de arremeçar.

Foi a atividade que eu mais gostei e eu estou com dificuldade de dançar

os paços são difcís e eu não consigo fazer. mas é muinto legar a professora de Ed. Fisica e muito legal as aulas dela e muito boa. e eu tan ben gostei da dança. FIM"

Fonte: Dados dos autores

A produção da narrativa presente na Figura 5 tomou como referência duas questões: "O que gostei de aprender nas aulas de Educação Física? O que gostaria de aprender?". Produzido em todos os trimestres, esse tipo de registro tem possibilitado à professora acompanhar 0 aprendizado dos alunos, à medida que narram os acontecimentos, transformando-os em experiências.

As crianças expressam satisfação pelas aulas de Educação Física não apenas pelo que aprenderam, mas, especialmente, pela relação epistêmica com o saber e aproximação com os professores. Lorena (Figura 5) ressalta as suas dificuldades em dominar corporalmente o conteúdo dança, formulando análises e sínteses do processo vivido. No entanto, pela relação de proximidade com a docente, aquela prática que antes se configurava de difícil entendimento agora se constitui, ao final de sua narrativa, como aquela em que também houve identificação. 
Possivelmente, o gosto pela dança não foi provocado por um correto desenvolvimento dos passos coreográficos, mas pela admiração atribuída à professora. As relações com o saber inscritas no domínio ou não de uma atividade e nas relações interpessoais implicam para a docente, nesse caso, a necessidade de uma mediação que amplie e motive o processo de apropriação do conteúdo dança, assim como o estabelecimento de critérios para inseri-lo e sistematizá-lo na escolarização.

No diário produzido, as diferentes linguagens utilizadas sinalizam ao leitor que palavra e ilustração interagem na compreensão das narrativas. Embora a representação visual sobre a aula da qual mais gostou seja diferente daquela expressa no texto, é preciso, de acordo com Bruzzo (2004), pensar a relação entre imagem e escrita para além do estatuto conferido a esses meios de comunicação, sobretudo quando é atribuída uma função acessória ao desenho, em que se pressupõe a necessidade de "[...] ser acompanhado por um texto que the dará sentido" (BRUZZO, 2004, p.1361). Para o autor, as ilustrações podem expressar conhecimentos que nem sempre são possíveis de traduzir por meio da escrita.

Uma descrição do desenho evidenciará o modo criterioso com o qual ele foi produzido. A criança traz elementos que conferem especificidade a uma modalidade esportiva, no caso, a ginástica rítmica. Ela reproduz uma formação coreográfica, especifica alguns dos seus apareIhos e demonstra entender as suas regras ao desenhar apenas meninas manejando os arcos e as fitas, assim como ao caracterizá-las pelo uso de cores semelhantes em seus collants, nos dois pequenos grupos desenhados. Pelo diálogo com Bruzzo (2004) é possível que a criança tenha narrado detalhadamente, por meio da ilustração, um conteúdo que também fosse de seu interesse, porém, por sua complexidade gestual, é dificilmente descrito, tendo em vista o domínio que exerce sobre a linguagem escrita, naquele momento da escolarização. Outra possibilidade de análise é de que a criança entenda a ginástica rítmica, devido à musicalidade que envolve os seus movimentos, como dança.

O diário também foi usado com a turma de $3^{\circ}$ ano, ao final do processo, com o objetivo de identificar as práticas corporais vivenciadas na Educação Física no ano anterior e no ano em que foi produzido, como é o caso da Figura 6 . A professora objetivou ainda usar as análises dos diários para projetar novas ações.

Figura 6 - Diário de Leyslane

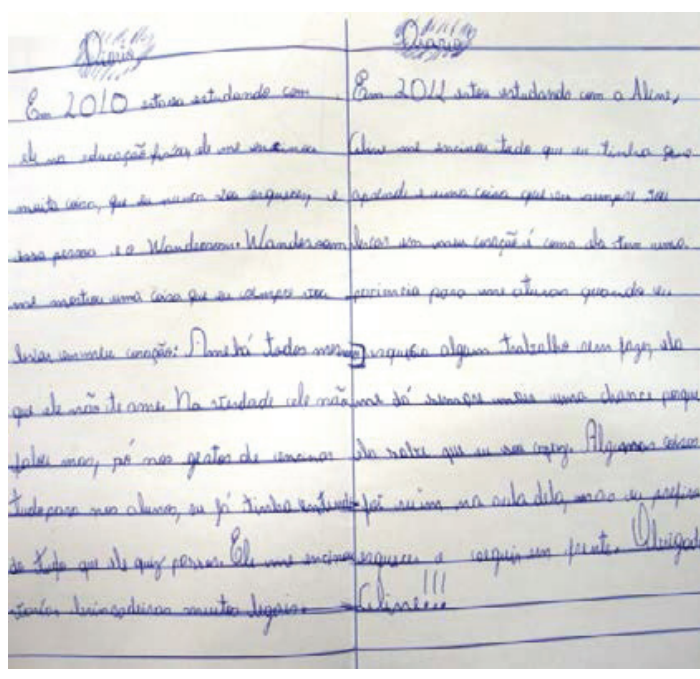

Fonte: Dados dos autores
Legenda: "Em 2010 estava estudando com ele na educação física, ele me ensinou muita coisa, que eu nunca vou esquecer, e essa pessoa é o Wanderson. Wanderson me mostrou uma coisa que eu sempre vou levar no meu coração. Ame a todos mesmo que ele não te ame. $\mathrm{Na}$ verdade ele não me falou, mas só nos gestos de ensinar tudo para os alunos, eu já tinha entendido tudo que ele quis passar. Ele me ensinou várias brincadeiras muitos legais. Em 2011 estou estudando com a Aline, Aline me ensinou tudo que eu tinha que aprender e uma coisa que eu sempre vou levar em meu coração é que ela tem uma paciência para me aturar quando eu esquecia algum trabalho sem fazer, ela me dá sempre mais uma chance porque ela sabe que eu sou capaz. Algumas coisas foram ruins na aula dela, mas eu prefiro esquecer e seguir em frente. Obrigada Aline!" 
De maneira geral, os diários convidam o leitor a perceber o que aconteceu nas aulas, o conteúdo ensinado, bem como os sentidos produzidos pelos alunos nas relações estabelecidas com a disciplina Educação Física e com os sujeitos que dela participam. É preciso destacar que as crianças endereçam a sua narrativa para os docentes, tanto no que tange ao reconhecimento do aprendizado provocado por eles, como pela maneira como agem com a turma.

Temos, no diário de Lorena e no de Leylane, o destaque para o saber relacional, que se configura no diálogo com o professor. Em foco está o modo como os professores vão marcando a trajetória de formação dos alunos no momento em que promovem a sua valorização pessoal e social. $O$ fato de os professores acreditarem que o aluno é capaz e merecedor de novas oportunidades, como destaca Leylane, aproxima-os de uma leitura positiva da realidade e, portanto, da própria avaliação.

No dizer de Charlot (2000), uma leitura positiva é prestar atenção ao que os alunos fazem, conseguem, sabem da vida, são, e não somente às suas falhas. Para o autor a leitura positiva é, antes de tudo, uma postura epistemológica e metodológica. Desse modo, praticar uma leitura positiva não é, segundo ele, apenas, nem fundamentalmente, perceber conhecimentos adquiridos ao lado de carências; é ler de outra maneira o que é lido como leitura negativa. 0 autor afirma que,

Assim, ante um aluno que fracassa num aprendizado, uma leitura negativa fala em deficiências, carências, lacunas e faz entrar em jogo os processos de reificação e aniquilamento que analisamos, enquanto que uma leitura positiva se pergunta 'o que está ocorrendo', qual a atividade implementada pelo aluno, qual o sentido da situação para ele, qual o tipo das relações mantidas com os outros, etc. A leitura positiva busca compreender como se constrói a situação do aluno que fracassa em um aprendizado e, não 'o que falta' para essa situação ser uma situação de aluno bem-sucedido (CHARLOT, 2000, p. 30).

A leitura positiva nos acena para outra perspectiva avaliativa em que o não saber se configura como oportunidade de aprendizado. A tarefa do avaliador se constitui, portanto, em um permanente exercício de interpretação de sinais, configurando-se como um processo de reflexão sobre e para a ação e contribuindo para que o professor e o aluno se tornem capazes de perceber indícios, de atingir níveis de complexidade na interpretação de seus significados e de incorporá-los como eventos relevantes para a dinâmica ensino-aprendizagem (SANTOS, 2008). Ao tomar o processo de aprendizagem/desenvolvimento de forma prospectiva, e enfatizando a natureza coletiva, compartilhada, do processo de tessitura de conhecimentos, Esteban (1998) fortalece a necessidade de indagar a relação saber/não saber estabelecida nas práticas escolares, possibilitando novos olhares para a dinâmica pedagógica da avaliação.

A autora procura substituir a interpretação unívoca, de natureza excludente, que propõe a avaliação como um processo articulado pela distinção entre erro e acerto, por uma orientação dialógica, que pressupõe inclusão e multiplicidade. 0 desafio está em romper as dicotomias erro/acerto, saber/não saber, imprimindo outra grafia no processo de tessitura de conhecimento e vislumbrando essas dicotomias como complementares e complexas. Ao trabaIhar com a dimensão do erro como processo que se revela no que denomina ainda-não-saber do aluno, ou como dimensão de potência, não de deficiência, Hoffmann (2001) redimensiona a sua noção, entendendo o erro como um importante elemento para a percepção da diversidade de lógicas e de conhecimentos que circulam no contexto escolar e se plasmam nas respostas dos envolvidos no processo. 
Oferecendo visibilidade à ambiguidade, incorpora-a como um sinal de que as conclusões devem ser relativizadas e continuamente interrogadas. É preciso procurar entender a lógica do outro, pois a diferença sinaliza novas possibilidades (ESTEBAN, 2002a). Nessa direção, Esteban (2002b), ao apresentar a sala de aula como espaço plural, ressalta a necessidade de criar condições para a interpretação das experiências múltiplas que os sujeitos trazem para o cotidiano, favorecendo a apropriação das interpretações e conhecimentos que se mostrem necessários. 0 professor precisa apropriar-se da compreensão do aluno, eixo do processo de avaliação, pois uma resposta diferente da esperada não significa ausência de conhecimento, pode ser uma solução criativa com a utilização das ferramentas e conhecimentos que ele possui.

\section{CONSIDERAÇÕES FINAIS}

A pesquisa teve por objetivo discutir a necessidade de mudança de compreensão sobre a avaliação do processo ensino-aprendizagem, tendo em vista a lógica da escola e a especificidade da Educação Física como componente curricular. Por meio de instrumentos de registros produzidos por alunos do $1^{\circ}$ ao $3^{\circ}$ ano do ensino fundamental, referenciamo-nos na teoria do saber, nas figuras do aprender (CHARLOT, 2000), na perspectiva da avaliação como prática indiciária (SANTOS, 2005, 2008) e como investigação (ESTEBAN, 2002c) para analisar os sentidos atribuídos ao que é vivenciado nas aulas e as suas implicações para as práticas avaliativas da professora.

As narrativas evidenciam a natureza dos saberes privilegiados pela Educação Física, aqueles incorporados pelo saberes de domínio e relacional. Ao fazer com (SCHNEIDER; BUENO, 2005) no aprendizado das práticas corporais, as crianças encarnam as experiências vividas nas aulas e produzem, na relação com o mundo, com o eu e com o outro, um diálogo com as demais figuras do aprender. No entanto, o fato de elas privilegiarem a dimensão do fazer com não exclui a possibilidade de materializar o saber incorporado pelo domínio de uma atividade e o produzido pela dimensão relacional em dispositivos de leitura, como a atividade "montando frases" e o diário de Educação Física, embora essa não seja sua especificidade, tampouco seu objetivo. Parte-se, assim, das práticas encarnadas no corpo para produzir instrumentos de registros que se configuram como saberes-objetos, permitindo outros tipos de apropriação.

As práticas avaliativas da professora sinalizaram o potencial da linguagem escrita como meio de os alunos expressarem as formas particulares com as quais se implicam no processo de aprendizagem, como se percebem e veem o outro, traduzindo melhor, especialmente no diário, o modo como produzem saberes na relação consigo e com os demais sujeitos. Por sua vez, os registros imagéticos possibilitaram a compreensão de como os conteúdos são dominados corporalmente, configurando-se em instrumentos que permitem às crianças não apenas sistematizar uma explicação do que aprenderam em forma de enunciados, mas expressar a experiência vivenciada por meio de recursos visuais.

Embora tenhamos aprofundando a discussão sobre o uso do desenho e do diário como instrumentos avaliativos, são necessárias pesquisas que articulem o conteúdo desses instrumentos com narrativas orais a respeito dos seus usos nas aulas de Educação Física, a fim de compreendermos as releituras dos alunos sobre os instrumentos produzidos por eles ao longo da escolarização. 


\section{REFERÊNCIAS}

ALVES, Nilda et al. Nós e nossas histórias em imagens e sons: uma história em imagens. In: AMORIM, A. C. R. de (Org.). Passagens entre o moderno para o pós-moderno: ênfase e aspectos metodológicos das pesquisas sobre currículo. Campinas, SP: Unicamp, GT Currículo da Anped, 2007. p. 21-28.

ALVES, W. F.; SOARES JÚNIOR, N. E. Educação física escolar e a avaliação: análise dos trabalhos apresentados no GTT-Escola no período de 1997 a 2005. In: CONGRESSO BRASILEIRO DE CIÊNCIAS DO ESPORTE, 15., 2007, Recife. Anais... Recife: Colégio Brasileiro de Ciência do Esporte, 2007.

BENJAMIN, W. Passagens. Belo Horizonte: UFMG Editora, 1994.

BORBA, A. M. A infância na escola e na vida: uma relação fundamental. In: BEAUCHAMP, J.; PAGEL, S. D.; NASCIMENTO, A. R. Ensino fundamental de nove anos. Brasília: MEC, 2007. p. 33-46. BRUZZO, C. Biologia: Educação e imagens. Educação \& Sociedade, Campinas, v. 25, n. 89, p. 1359-1378, set./dez. 2004.

CECHELLA, J. C. A avaliação em educação física: uma nova perspectiva. Revista Kinesis, Santa Maria, n. 8, p. 65-76, dez. 1991.

CERTEAU, M. de. A invenção do cotidiano: artes de fazer. 8. ed. Petrópolis, RJ: Vozes, 1994.

CHARLOT, B. Da relação com o saber: elementos para uma teoria. Porto Alegre: Artes Médicas, 2000.

CHARLOT, B. Ensinar a educação física ou ajudar o aluno a aprender o seu corpo-sujeito? In: DANTAS JÚNIOR, H. S.; KUHN, R.; RIBEIRO, S. D. D. Educação física, esporte e sociedade: temas emergentes. São Cristóvão: Editora da UFS, 2009. v. 3, p. 231-246.

DIÓGENES, G. Imagens e narrativas: registros afetivos. Perspectiva, Florianópolis, v. 22, n. 2, p. 471-493, jul./dez. 2004.

ESTEBAN, M. T. Alfabetização sob diferentes pontos de vista - avaliação: reconstruindo práticas e redefinindo saberes. In: ENCONTRO NACIONAL DE DIDÁTICA E PRÁTICA DE ENSINO, 9., 1998, Águas de Lindóia. Anais... Águas de Lindóia: Endipe, 1998.

ESTEBAN, M. T. A avaliação no cotidiano escolar. In: ESTEBAN, M. T. (Org.). Avaliação: uma prática em busca de novos sentidos. 4. ed. Rio de Janeiro: DP\&A, 2002a. p. 7-28.

ESTEBAN, M. T. A avaliação no processo ensino/aprendizagem: os desafios postos pelas múltiplas faces do cotidiano. Revista Brasileira de Educação, Rio de Janeiro, n. 19, p. 130-137, jan./abr. 2002b.

ESTEBAN, M. T. 0 que sabe quem erra? reflexões sobre avaliação e fracasso escolar. 3. ed. Rio de Janeiro: DP\&A, 2002C.

ESTEBAN, M. T. Ser professora: avaliar e ser avaliada. In: ESTEBAN, M. T. (Org.). Escola, currículo e avaliação. São Paulo: Cortez, 2003. p. 13-37.

HADJI, C. Avaliação, regras do jogo: das intenções aos instrumentos. Porto Alegre: Artes Médicas, 1994.

HÉBRARD, J. A escolarização dos saberes elementares na época moderna. Teoria \& Educação, Porto Alegre, n. 2, p. 65-107, 1990.

HOFFMANN, J. Avaliar para promover: as setas do caminho. Porto Alegre: Mediação, 2001.

LOPES, S. de C. Imagens de um lugar de memória da Educação Nova: Instituto de Educação do Rio de Janeiro nos anos de 1930. Revista Brasileira de Educação, Rio de Janeiro, v. 13, n. 13, jan./abr. 2008.

LUCKESI, C. A avaliação da aprendizagem escolar. São Paulo: Cortez, 2000.

LUCKESI, C. Primeira constatação: a escola pratica mais exames que avaliação. In: LUCKESI, C.

Avaliação da aprendizagem: componente como ato pedagógico. Cortez: São Paulo, 2011. 
LUIS, S. M. B. De que avaliação precisamos em arte e educação física? In: SILVA, J. F.; HOFFMANN, J.; ESTEBAN, M. T. (Org.). Práticas avaliativas e aprendizagens significativas em diferentes áreas do currículo. 8. ed. Porto Alegre: Editora Mediação, 2010. p. 35-46.

MACEDO, L. R.; MAXIMIANO, F. L.; SANTOS, W. Avaliação na educação física escolar: uma análise da produção acadêmica. In: SEMINÁRIO CURRÍCULOS, COTIDIANOS, CULTURAS E FORMAÇÃO DE EDUCADORES, 1., 2011, Vitória. Anais... Vitória: Núcleo de pesquisa e extensão em currículos, culturas e cotidianos, 2011.

RAMOS, F. B.; PANOZZO, N. S. P.; ZANOLLA, T. Imagem e palavra na leitura de narrativa.

Perspectiva, Florianópolis, v. 29, n. 1, p. 245-262, jan./jun. 2011.

SANTOS, W. dos. Avaliação na educação física escolar: análise de periódicos do século XX. 2002. 138 f. Monografia (Licenciatura em Educação Física) - Centro de Educação Física e Desportos, Universidade Federal do Espírito Santo, Vitória, 2002.

SANTOS, W. dos. Currículo e avaliação na educação física: do mergulho à intervenção. Vitória: Proteoria, 2005.

SANTOS, W. dos. Currículo e avaliação na educação física: práticas e saberes. In: SCHNEIDER, 0. et al. (Org.). Educação física esporte e sociedade: temas emergentes. São Cristovão: Editora da UFS, 2008. v. 2, p. 87-106.

SANTOS, W. dos; MAXIMIANO, F. de L. Avaliação na educação física escolar: singularidades e diferenciações de um componente curricular. Revista Brasileira de Ciências do Esporte, Florianópolis, v. 35, n. 4, p. 883-896, out./dez. 2013.

SCHNEIDER, O.; BUENO, J. G. A relação dos alunos com o saber compartilhado nas aulas de educação física. Revista Movimento, Porto Alegre, v. 11, n. 1, p. 23-46, jan./abr. 2005.

SOUZA, E. C. A arte de contar e trocar experiência: reflexões teórico-metodológicas sobre história de vida em formação. Revista Educação em Questão, Natal, v. 25, n. 11, p. 222-39, jan./abr. 2006. 
